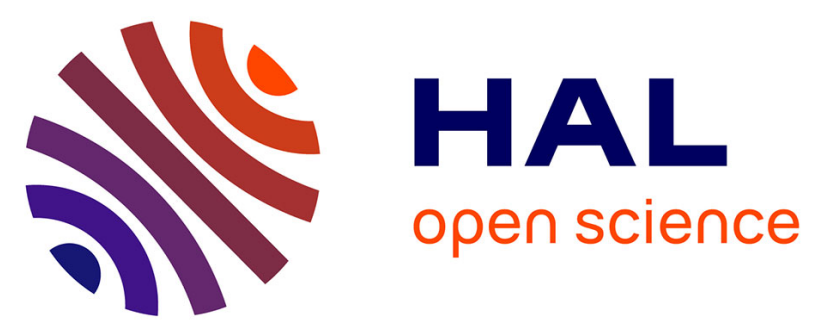

\title{
Serum calprotectin is increased in early axial spondyloarthritis with sacroiliitis and objective signs of inflammation: Results from the DESIR cohort
}

Xavier Romand, Marie-Hélène Paclet, Anaïs Courtier, Minh Vu Chuong Nguyen, Daniel Wendling, Francis Berenbaum, Philippe Gaudin, Athan Baillet

\section{To cite this version:}

Xavier Romand, Marie-Hélène Paclet, Anaïs Courtier, Minh Vu Chuong Nguyen, Daniel Wendling, et al.. Serum calprotectin is increased in early axial spondyloarthritis with sacroiliitis and objective signs of inflammation: Results from the DESIR cohort. Joint Bone Spine, 2021, 88 (1), pp.105068. 10.1016/j.jbspin.2020.08.003 . hal-03511725

\section{HAL Id: hal-03511725 \\ https://hal.sorbonne-universite.fr/hal-03511725}

Submitted on 5 Jan 2022

HAL is a multi-disciplinary open access archive for the deposit and dissemination of scientific research documents, whether they are published or not. The documents may come from teaching and research institutions in France or abroad, or from public or private research centers.
L'archive ouverte pluridisciplinaire HAL, est destinée au dépôt et à la diffusion de documents scientifiques de niveau recherche, publiés ou non, émanant des établissements d'enseignement et de recherche français ou étrangers, des laboratoires publics ou privés. 


\section{Serum calprotectin is increased in early axial spondyloarthritis with sacroiliitis and objective signs of inflammation: results from the DESIR cohort}

Authors: Xavier Romand ${ }^{a, b}$, Marie-Hélène Paclet ${ }^{b, c}$, Anaïs Courtier ${ }^{d}$, Minh Vu Chuong Nguyen $^{\mathrm{b}, \mathrm{d}}$, Daniel Wendling ${ }^{\mathrm{e}}$, Francis Berenbaum ${ }^{\dagger}$, Philippe Gaudin ${ }^{\mathrm{a}, \mathrm{b}}$, Athan Baillet ${ }^{\mathrm{a}, \mathrm{b}}$ Affiliate:

a Department of Rheumatology, CHU Grenoble Alpes, Echirolles, France

b Univ. Grenoble Alpes, GREPI TIMC, CNRS UMR 5525, Grenoble, France

${ }^{c}$ Department of Biology, CHU Grenoble Alpes, La Tronche, France

d Sinnovial, Grenoble, France

e Department of Rheumatology, University Teaching Hospital (CHRU), Besançon, and EA4266, Université Bourgogne Franche-Comté, Besançon, France

${ }^{\dagger}$ Department of Rheumatology, Sorbonne Université, INSERM CRSA, AP-HP Saint-Antoine Hospital, Paris, France

Corresponding author: Xavier Romand, Department of Rheumatology, CHU Grenoble Alpes Hôpital Sud, 19 Avenue de Kimberley, 38130 Échirolles, France.

E-mail: xromand@chu-grenoble.fr

ORCid iD: https://orcid.org/0000-0003-2222-1456

Letter to the editor: $499 / 500$ words

Keywords: calprotectin, S100 proteins, spondyloarthritis, biomarker, structural damage 
Axial Spondyloarthritis $(\mathrm{axSpA})$ is a chronic inflammatory disease that affects spine and sacroiliac joint (SIJ) leading to highly variable spinal radiographic damages in the individual patient [1]. Inflammation appears to be a determining factor of developing future structural damage $[2,3]$. The quantification of inflammation in axSpA remains a challenge [4]. Calprotectin, an alarmin secreted by activated myeloid cells, has been suggested as a biomarker predicting radiographic spinal progression at 2 years in established ankylosing spondylitis (AS) [5-7]. The aim was to assess whether serum calprotectin was associated with inflammation and spinal radiographic progression within 2 years in early axSpA.

Patients with recent-onset inflammatory back pain, suggestive of axSpA from the DESIR cohort (NCT01648907) were included [8]. Assessment in SpondyloArthritis Society (ASAS) and modified New York criteria were respectively used for classification of axSpA and AS patients. Serum calprotectin was assessed at baseline (Calprotectin ELISA kit, Hycult Biotech). Radiographic spinal progression was defined as worsening by $\geq 2$ units of the modified Stoke Ankylosing Spondylitis Spine Score 2 years after the inclusion. Spine and SIJ magnetic resonance imaging (MRI) inflammation were graded with the Spondyloarthritis Research Consortium of Canada (SPARCC) score.

At baseline, calprotectin was assessed in 426 early axSpA, including 149 patients with AS (Table 1). Serum calprotectin level was not significantly different between patients with recent-onset inflammatory back pain fulfilling $v s$. those not the ASAS criteria. High level of calprotectin was observed in axSpA with sacroiliitis, nonradiographic axSpA with objective signs of inflammation (i.e. with sacroiliitis on MRI and/or elevated CRP levels) and AS (Figure 1A-B). A total of $211 \mathrm{axSpA}$ and 77 AS patients had both baseline and 2 years mSASSS scoring. Fifteen (15/211, 7.1\%) 
axSpA and seven (7/77, 9.1\%) AS had a radiographic spinal progression within 2 years. Serum calprotectin levels did not identify patients with subsequent radiographic progression and was not increased in axSpA with syndesmophytes $(\geq 1)$ or with significative SIJ erosions $(\geq 3)$ and fat lesions $(\geq 3)$ on MRI. axSpA patients with high disease activity index score (BASDAI>4 and ASDAS>3.5) and high SIJ and spine SPARCC scoring $(\geq 5)$ showed an elevated calprotectin level (Figure 1 C-F). Calprotectin correlated with inflammatory parameters as CRP $\left(r_{s}=0.32, p<0.01\right)$, ESR $\left(r_{s}=0.23, p<0.0001\right), I L-6\left(r_{s}=0.24, p<0.0001\right), I L-31\left(r_{s}=0.17, p<0.001\right)$, SCD40L $\left(r_{s}\right.$ $=0.13, p<0.05)$ but not with TNF.

The present study shows that calprotectin is associated with inflammatory parameters, $\mathrm{MRI}$ inflammation rather than structural lesions in early axSpA. These results are in line with previous study [9]. We do not confirm, as observed in establish AS patient [5], that calprotectin level is a factor associated with spinal radiographic progression in early axSpA and AS. Nevertheless, this analysis is limited by a lack of statistical power to detect small effect size. Structural damage in axSpA is definitely a complex phenomenon hardly captured by a single biomarker assay compared to a biomarker combination strategy [10].

In conclusion, calprotectin in early axSpA seems to reflect the local inflammatory process involving myeloid cells in SIJ and spine. 
Fundings: The DESIR-cohort is financially supported by unrestricted grants from the Société Française de Rhumatologie (SFR) and Pfizer. No specific funding was received from any bodies in the public, commercial or not-for-profit sectors to carry out the work described in this article. Pfizer did not review the content or have influence on this manuscript.

\section{Acknowledgements:}

The DESIR cohort was sponsored by the Département de la Recherche Clinique et du Développement de l'Assistance Publique-Hôpitaux de Paris. This study is conducted under the umbrella of the French Society of Rheumatology and INSERM (Institut National de la Santé et de la Recherche Médicale). The database management is performed within the department of epidemiology and biostatistics (Professor Paul Landais, D.I.M., Nîmes, France). An unrestricted grant from Pfizer was allocated for the first 10 years of the follow-up of the recruited patients. The authors thank the different regional participating centers: Professor M Dougados (Paris-Cochin B), Professor A Kahan (Paris-Cochin A), Professor P Dieudé (Paris-Bichat), Pr L Gossec (Paris-Pitié-Salpetrière), Professor F Berenbaum (Paris-Saint Antoine), Professor P Claudepierre (Créteil), Professor M. Breban (Boulogne Billancourt), Dr B. Saint-Marcoux (Aulnay-sous-Bois), Professor P Goupille (Tours), Professor J-F. Maillefert (Dijon), Dr E Dernis (Le Mans), Professor D Wendling (Besançon), Professor B Combe (Montpellier), Professor L Euller-Ziegler (Nice), Professor P Orcel, Professor P Richette (Paris_Lariboisière), Professor P Lafforgue (Marseille), Dr P Boumier (Amiens), Professor M Soubrier (Clermont-Ferrand), Dr $\mathrm{N}$ Mehsen (Bordeaux), Professor D Loeuille (Nancy), Professor R-M Flipo (Lille), Professor A Saraux (Brest), Dr S Pavy (Kremlin Bicêtre), Professor A Cantagrel (Toulouse), Professor O Vittecoq 
(Rouen). The authors also thank URC-CIC Paris Centre for the coordination and monitoring of the study and Sylvie Papacatzis for performing the serum calprotectin assays.

Disclosure of interest: The authors declare that they have no competing interest. 

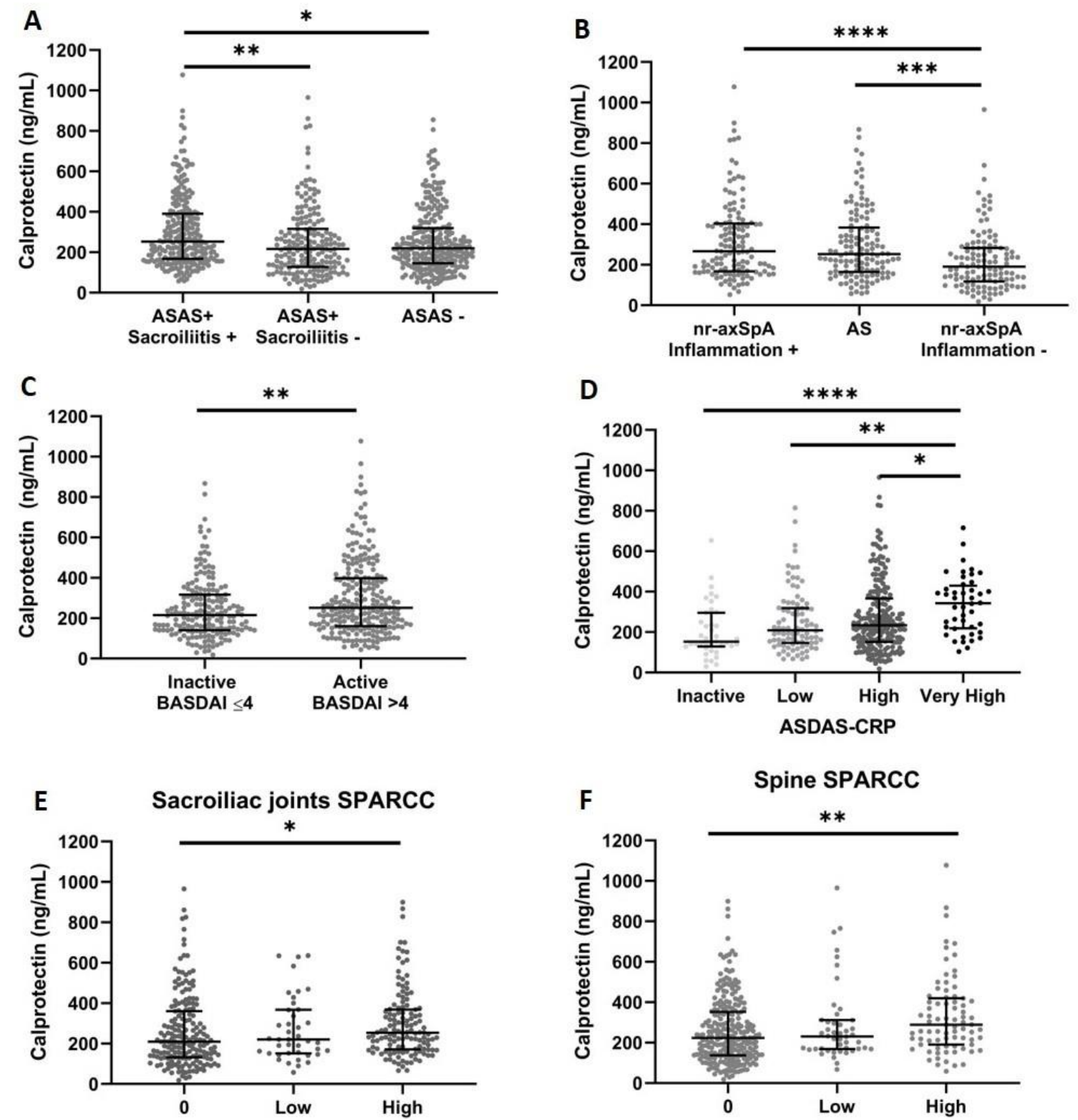

\section{Figure 1. Serum calprotectin level is increased in early axial spondyloarthritis with sacroiliitis and objective signs of inflammation}

Serum calprotectin levels at baseline $(A)$ in early axial $\mathrm{SpA}(\mathrm{axSpA})$ patients fulfilling axial ASAS criteria (ASAS+) with sacroiliitis (sacroiliitis + ) or not (sacroiliitis -) on X-ray or magnetic resonance imaging (sacroiliitis +) compared to those not fulfilling (ASAS-) and (B) in non-radiographic axSpA (nr-axSpA) patient with objective signs of inflammation (sacroiliitis + or elevated C-reactive protein level) (inflammation +), AS and those without objective signs of inflammation (inflammation -). (C) Serum calprotectin levels according to disease activity assessed with Bath Ankylosing Spondylitis Disease Activity Index (BASDAI), (D) Ankylosing Spondylitis Disease Activity Score with CRP (ASDAS-CRP) and Spondyloarthritis Research Consortium of Canada (SPARCC) magnetic resonance imaging score of the $(E)$ sacroiliac joints and $(F)$ spine. Inactive: ASDAS<1.3, Low: 1.3-2.1, High: 2.1-3.5 and Very High: ASDAS $>3.5$. 0: SPARCC score=0, Low: $2 \leq S P A R C C$ score $<5$ and High: SPARCC score $\geq 5$. Each point represents a subject, horizontal and vertical lines show the median and interquartile range. $\mathrm{p}<0.05,{ }^{* *} \mathrm{p}<0.01,{ }^{* * *} \mathrm{p}<0.001,{ }^{* * * *} \mathrm{p}<0.0001$ with Mann-Whitney $U$ test or Kruskal-Wallis one-way test with post hoc Dunn's test. 
Table 1. Baseline characteristics of axial spondyloarthritis patients included from the DESIR cohort.

\begin{tabular}{|c|c|c|c|}
\hline Baseline characteristics & $\begin{array}{l}\text { axSpA } \\
\text { ASAS+ } \\
(n=426)\end{array}$ & $\begin{array}{c}\text { AS mNY+ } \\
(n=149)\end{array}$ & $p$-value \\
\hline Males (\%) & 51.9 & 62.8 & $<0.05$ \\
\hline Age (years, mean \pm SD) & $31.4 \pm 7.2$ & $32.1 \pm 8.5$ & NS \\
\hline $\begin{array}{l}\text { Disease duration (months, } \\
\text { mean } \pm S D \text { ) }\end{array}$ & $10.4 \pm 23.0$ & $13.1 \pm 24.5$ & NS \\
\hline HLA B27 positivity (\%) & 86.1 & 74.3 & $<0.01$ \\
\hline $\begin{array}{l}\text { CRP level baseline }(\mathrm{mg} / \mathrm{L} \text {, } \\
\text { mean } \pm \mathrm{SD})\end{array}$ & $8.9 \pm 14.0$ & $12.7 \pm 17.0$ & $<0.01$ \\
\hline elevated CRP & 34.1 & 48.6 & $<0.01$ \\
\hline BASDAI (mean \pm SD) & $42.7 \pm 20.3$ & $40.3 \pm 19.2$ & NS \\
\hline ASDAS-CRP (mean $\pm S D)$ & $2.6 \pm 1.0$ & $2.7 \pm 1.0$ & NS \\
\hline BASFI (mean \pm SD) & $28.8 \pm 22.1$ & $30.2 \pm 23.2$ & NS \\
\hline mSASSS (mean $\pm S D)$ & $1.5 \pm 4.0$ & $1.9 \pm 4.2$ & $<0.05$ \\
\hline $\begin{array}{l}\text { Serum calprotectin }(\mathrm{ng} / \mathrm{mL} \text {, } \\
\text { mean } \pm \mathrm{SD})\end{array}$ & $271.4 \pm 170.0$ & $268.0 \pm 156.1$ & NS \\
\hline Total Berlin score & $1.2 \pm 2.9$ & $2.7 \pm 4.5$ & $<0.0001$ \\
\hline SIJ SPARCC score & $5.6 \pm 9.3$ & $10.0 \pm 12.0$ & $<0.0001$ \\
\hline Spine SPARCC score & $4.6 \pm 13.1$ & $10.6 \pm 20.8$ & $<0.0001$ \\
\hline
\end{tabular}

axSpA ASAS+: axial Spondyloarthritis fulfilling axial Assessment of Spondyloarthritis international Society criteria, AS mNY+: Ankylosing Spondylitis fulfilling modified New York criteria, HLA B27: Human Leukocyte Antigen B27, CRP: C-reactive protein, elevated CRP: CRP above 5mg/L, BASDAl: Bath Ankylosing Spondylitis Disease Activity Index, ASDAS: Ankylosing Spondylitis Disease Activity Score, BASFI: Bath Ankylosing Spondylitis Spine Score, mSASSS: modified Stoke Ankylosing Spondylitis Spine Score, SIJ: sacro-iliac joint, SPARCC: Spondyloarthritis Research Consortium of Canada. P-values refer to Mann-Whitney U test result and Fisher's exact test. NS: non-significant 


\section{REFERENCES}

[1] Ramiro S, Stolwijk C, van Tubergen A, et al. Evolution of radiographic damage in ankylosing spondylitis: a 12 year prospective follow-up of the OASIS study. Ann Rheum Dis 2015;74:52-9.

[2] Machado PM, Baraliakos X, van der Heijde D, Braun J, Landewé R. MRI vertebral corner inflammation followed by fat deposition is the strongest contributor to the development of new bone at the same vertebral corner: a multilevel longitudinal analysis in patients with ankylosing spondylitis. Ann Rheum Dis 2016;75:1486-93.

[3] Poddubnyy D, Haibel H, Listing J, et al. Baseline radiographic damage, elevated acutephase reactant levels, and cigarette smoking status predict spinal radiographic progression in early axial spondylarthritis. Arthritis and rheumatism 2012;64:1388-98.

[4] Benhamou M, Gossec L, Dougados M. Clinical relevance of C-reactive protein in ankylosing spondylitis and evaluation of the NSAIDs/coxibs' treatment effect on Creactive protein. Rheumatology (Oxford, England) 2010;49:536-41.

[5] Turina MC, Sieper J, Yeremenko N, et al. Calprotectin serum level is an independent marker for radiographic spinal progression in axial spondyloarthritis. Ann Rheum Dis 2014;73:1746-8.

[6] Romand X, Bernardy C, Nguyen MVC, et al. Systemic calprotectin and chronic inflammatory rheumatic diseases. Joint bone spine 2019;86:691-8.

[7] Edgeworth J, Gorman M, Bennett R, Freemont P, Hogg N. Identification of p8,14 as a highly abundant heterodimeric calcium binding protein complex of myeloid cells. The Journal of biological chemistry 1991;266:7706-13.

[8] Dougados M, d'Agostino MA, Benessiano J, et al. The DESIR cohort: a 10-year followup of early inflammatory back pain in France: study design and baseline characteristics of the 708 recruited patients. Joint bone spine 2011;78:598-603.

[9] Huang J, Yin Z, Song G, Cui S, Jiang J, Zhang L. Discriminating Value of Calprotectin in Disease Activity and Progression of Nonradiographic Axial Spondyloarthritis and Ankylosing Spondylitis. Disease markers 2017;2017:7574147.

[10] Rademacher J, Tietz LM, Le L, et al. Added value of biomarkers compared with clinical parameters for the prediction of radiographic spinal progression in axial spondyloarthritis. Rheumatology (Oxford, England) 2019;58:1556-64. 